\title{
Serum and Bile Insulin-Like Growth Factor I, Interleukin-6 and Tumor M2- Pyruvate Kinase in Differentiation Malignant from Benign Biliary Strictures - Preliminary Report
}

Agnieszka Budzynska*, Ewa Nowakowska-Dulawa, Tomasz Marek and Marek Hartleb

Department of Gastroenterology and Hepatology, Medical University of Silesia in Katowice, Poland Medyków Str. 14, 40-752 Katowice, Poland

\begin{abstract}
Objective: To determine the value of serum and bile insulin-like growth factor I (IGF-I), interleukin-6 (II-6) and tumor M2-pyruvate kinase (Tu M2-PK) in distinguishing pancreatobiliary cancers from benign biliary strictures.

Material and methods: The study was performed prospectively on forty jaundiced patients admitted for biliary decompression due to bile duct strictures. Malignant strictures were diagnosed in 22 patients including 15 cases of CCA and 7 cases of pancreatic cancer, and benign biliary strictures in 18 cases. IGF-I, II-6 and Tu M2-PK were measured in sera and bile by ELISA and compared to serum levels of carbohydrate antigens (CA) 19-9 and carcinoembryonic antigen (CEA).

Results: Serum levels of IGF-I ( 74.4 vs. $117.0 \mathrm{ng} / \mathrm{mL}, p=0.03)$, II-6 (37.1 vs. $17.0 \mathrm{pg} / \mathrm{mL}, p=0.04)$, CA19-9 $(5689$ vs. $38.9 \mathrm{U} / \mathrm{mL}, p<0.001)$ and $C E A(27.5$ vs. $1.9 \mathrm{ng} / \mathrm{mL}, p<0.0001)$ differed significantly between patients with malignant and benign biliary strictures, whereas biliary concentrations of IGF-I and II- 6 and serum and biliary levels of Tu M2-PK were comparable. Biliary IGF-I levels were significantly increased in pancreatic cancer as compared to cholangiocarcinoma and benign biliary strictures groups (966 vs. $137 \mathrm{ng} / \mathrm{mL}, p=0.03$ and $966 \mathrm{vs} .90 .6 \mathrm{ng} / \mathrm{mL}$, $p=0.01$, respectively). The AUC-ROCs for serum IGF-I and serum II- 6 were 0.336 and 0.606 , respectively, what was worse than that of CA 19-9 (0.855) and CEA (0.794).
\end{abstract}

Conclusion: Measurement of serum IGF-I and II-6 may be helpful in differentiation malignant from benign biliary strictures and biliary IGF-I seems to be a promising marker for distinguishing pancreatic cancer from cholangiocarcinoma and benign biliary occlusions.

Keywords: Insulin-like growth factor I; Interleukin-6; Tumor M2pyruvate kinase; Cholangiocarcinoma; Pancreatic cancer; Biliary strictures

\section{Introduction}

Cholangiocarcinoma (CCA) is an aggressive tumor arising from the bile duct epithelium, usually diagnosed at advanced stage, when obstructive jaundice, abdominal pain and weight loss dominate clinical image. Despite significant advances in radiologic and endoscopic approaches, the diagnosis of CCA remains highly challenging. Histopathologic confirmation is difficult to obtain as only minority of patients are eligible for surgery and endoscopic tissue sampling by brush smear or biopsy forceps have limited diagnostic sensitivity, generally not exceeding $60 \%[1,2]$. Widely used serum markers, such as carbohydrate antigen 19-9 (CA19-9) and carcinoembryonic antigen (CEA), are not specific for CCA and have unsatisfactory diagnostic sensitivity in early stages of cancer [3,4]. Serum CA19-9 levels are elevated in most patients with pancreatobiliary cancer, but its high concentrations are also seen in obstructive jaundice of benign origin. Moreover, $5-10 \%$ of general population with Lewis ${ }^{\mathrm{a}-\mathrm{b}-}$ phenotype cannot synthetize the CA19-9 antigen [5].

Reliable markers able to discriminate between benign and early malignant diseases of extrahepatic bile ducts would speed up diagnostic work-up of CCA, most likely increasing the percentage of resectable tumors. Because bile can be easily accessible during endoscopic procedures aimed to decompress biliary ducts in obstructive jaundice, there is also interest to search cancer biomarkers in the bile [6-9]. Together with others we have shown that neutrophil-gelatinase associated lipokalin (NGAL) measured in the bile provided more accurate information on nature of biliary stricture than its serum level $[7,8]$.

Recently numerous potential biomarkers of pancreatobiliary cancer have been disclosed. Insulin-like growth factor I (IGF-I) plays an important role in tumorigenesis by promoting growth and proliferation of neoplastic cells [10]. High expressions of IGF-I and its receptors were found in human CCA cells [10]. Elevated serum levels of IGF-1 were associated with increased risk for pancreatic cancer [11], while biliary IGF-I levels helped to differentiate CCA from either pancreatic cancer or benign biliary strictures [6].

Another potential biomarker is interleukin-6 (Il-6), a major mediator of inflammation and recognized mitogen of CCA [12]. The relationship between cholestasis and long lasting inflammation as trigger mechanisms of cholangiocarcinogenesis has been well established [13]. Il-6 may induce aberrant promoter DNA methylation resulting in silencing of several tumor suppressor genes $[14,15]$. Overexpression of Il-6 was found in human malignant cholangiocytes and was linked to cell survival and tumor progression [12]. Elevated serum Il-6 levels were found in CCA discriminating CCA from benign biliary diseases [16]. In addition, serum Il-6 levels significantly dropped after CCA resection or its photodynamic destruction $[17,18]$.

The putative new biomarker of CCA is the pyruvate kinase isoenzyme type M2 (M2-PK). PK is a key enzyme of the final step of

*Corresponding author: Agnieszka Budzynska, Department of Gastroenterology and Hepatology, Medical University of Silesia, Medyków Str 14, 40-752 Katowice, Poland, Tel: +4832789; Fax: +483278944034401; E-mail: budzynskaagnieszka@poczta.onet.pl

Received April 18, 2016; Accepted May 18, 2016; Published June 27, 2016

Citation: Budzynska A, Nowakowska-Dulawa E, Marek T, Hartleb M (2016) Serum and Bile Insulin-Like Growth Factor I, Interleukin-6 and Tumor M2-Pyruvate Kinase in Differentiation Malignant from Benign Biliary Strictures - Preliminary Report. Med chem (Los Angeles) 6: 429-434. doi:10.4172/2161-0444.1000381

Copyright: (c) 2016 Budzynska A, et al. This is an open-access article distributed under the terms of the Creative Commons Attribution License, which permits unrestricted use, distribution, and reproduction in any medium, provided the original author and source are credited. 
Citation: Budzynska A, Nowakowska-Dulawa E, Marek T, Hartleb M (2016) Serum and Bile Insulin-Like Growth Factor I, Interleukin-6 and Tumor M2-Pyruvate Kinase in Differentiation Malignant from Benign Biliary Strictures - Preliminary Report. Med chem (Los Angeles) 6: $429-434$. doi:10.4172/2161-0444.1000381

glycolysis, for which type M2 isoform is specific for all proliferating tissues, including cancer cells. The tetrameric form of M2-PK is enzymatically active, but after phosphorylation it shifts to an inactive dimeric form typical for tumors (Tu M2-PK). In consequence, accumulation of energy-rich metabolites enables cell proliferation, irrespective of hypoxic conditions [19]. Tu M2-PK expression was specific for CCA cells and correlated with tumor aggressiveness and prognosis [20]. The plasma and bile Tu M2-PK levels were found to be elevated in patients with CCA and were related to tumor stage and poor outcome $[20,21]$.

As far as we know there is only single study concerning the role of biliary IGF-I and one concerning Tu M2-PK in evaluation of bile ducts occlusions. We have not found any study measuring biliary Il6. Therefore the aim of the present study was to determine the value of serum and bile concentrations of IGF-I, Il-6 and Tu M2-PK in distinguishing pancreatobiliary cancers from benign biliary strictures compared to the accuracy of CA 19-9 and CEA.

\section{Materials and Methods}

\section{Patients}

The study was prospectively performed in tertiary gastroenterological center in patients qualified for endoscopic or percutaneous transhepatic biliary decompression due to obstructive jaundice. Forty patients (17 women, 23 men) with extrahepatic biliary tract strictures demonstrated by ultrasonography and confirmed by magnetic resonance cholangiography (MRC) or computed tomography (CT) were included. Gall stone disease, chronic pancreatitis, malignancy other than pancreatobiliary were excluded criteria. All endoscopic retrograde cholangiopancreatography (ERCP) examinations were planned as therapeutic procedures to stent or dilate biliary duct strictures and were performed by 4 operators aware of clinical diagnosis. The study was approved by local ethics committee (KNW/0022/KB1/98/10) and informed consent was received from each patient.

\section{Serum and bile samples}

Routine blood morphology (Sysmex XT-1800i) and serum biochemistry (Olympus AU680) were determined on the day of endoscopy procedure. Serum levels of CA19-9 and CEA were measured by immunoassay (CMIA Architect i2000SR). Bile was collected during ERCP or percutaneous transhepatic cholangiography (PTCA) immediately before contrast injection. Serum, EDTA plasma or bile were centrifuged for 15 minutes at $1500 \mathrm{~g}$ and immediately stored in small aliquots at $-80^{\circ} \mathrm{C}$.

Bile and serum levels of biomarkers were measured using a commercially available enzyme-linked immunosorbent assay kits; IGF-I by ELISA kit from Mediagnost, Reutlingen, Germany, Il- 6 by ELISA kit from Gen-Probe Diaclone SAS, Besançon, and-Tu M2-PK in EDTAplasma and bile by ELISA kit from ScheBo Biotech, Giessen, Germany.

\section{Statistical analysis}

Differences were compared by Mann-Whitney $U$ test or Student's $\mathrm{t}$-test as appropriate. The Kruskal-Wallis analysis of variance was used for comparisons of multiple groups. The Pearson Chi-squared test was used for comparisons between categorical variables. Receiver operating characteristic (ROC) analyses for selected serum and bile biomarkers were performed and the area under the ROCs curve (AUROCs) were obtained to compare the diagnostic accuracy of these variables to differentiate between benign and malignant biliary strictures. The optimal cut-off levels, sensitivity, specificity and accuracy were estimated from the ROC curve analysis. The Spearman rank test was performed for correlation analysis between continuous variables. A $P$ value of less than 0.05 was considered significant. Statistica 10 software (StatSoft Polska) was used for all statistical analyses.

\section{Results}

\section{Patient characteristics}

We presented preliminary report of forty patients ( 17 women, 23 men) with biliary duct strictures enrolled into the study. ERCP was performed in 36 of them and 4 had PTCA.

Malignant strictures were diagnosed in 22 patients, including 15 with cholangiocarcinoma and 7 with pancreatic cancer. Tumors were located in perihilar region in 10 patients and in the extrahepatic ducts in 5 patients. The diagnosis of pancreatobiliary cancer was based on the results of endoscopic and radiologic approaches with cytologic or histologic confirmation in $6(27 \%)$ cases through ERCP and another 7 (32\%) after surgery (Table 1). After the initial abdominal ultrasound most (21) patients had spiral CT (96\%), 9 (41\%) had MRCP and 1 (4.6\%) had EUS with FNAB. Perihilar CCA were classified as type IV of Bismuth classification in 9 cases and IIIa in a one case. None of them was operated. Three of five patients with distal cholangiocarcinoma were operated, two of them radically, whereas one appeared unresectable during surgery. Another two had advanced diseases confirmed by histology taking by biopsy forceps during ERCP. Four patients with pancreatic cancer were operated and confirmed histologically. From the remaining three advanced pancreatic tumors one was confirmed by cytology taken during ERCP and another one by EUS+FNA. Establishing of the final diagnosis was complex process based on endoscopic and radiologic imaging, cytology or histology, surgery and confirmed by natural history.

The benign biliary strictures were diagnosed in 18 cases, including 5 cases of primary sclerosing cholangitis, 12 cases of iatrogenic postoperative stenosis and 1 case of adenoma of the papilla Vater. During diagnostic work-up 12 (67\%) patients had CT, 9 (50\%) had MRCP and 1 (6\%) had EUS. Brush smear cytology was done in two patients during ERCP. Adenoma of papilla of Vater was confirmed by EUS+FNA. Surgical treatment was applied to six patients with bening biliary strictures, including 3 patients with primary sclerosing cholangitis who finally had liver transplantation.

Groups were comparable in terms of age, gender and BMI (Table 2). Diagnosis of malignancy was associated with lower hemoglobin level ( $12.1 \pm 1$ vs. $13.2 \pm 2$, p=0.03), higher platelet count ( $323 \pm 131$ vs. $213 \pm 105, \mathrm{p}=0.006$ ), significantly higher transaminases activities (ALT $150.4 \pm 109.6$ vs. $44 \pm 29.6, \mathrm{p}<0.001$ and AST $166.5 \pm 142.9$ vs. 47.8

\begin{tabular}{|c|c|c|c|c|}
\hline $\begin{array}{c}\text { Diagnostic procedure } \\
\text { /treatment/follow-up }\end{array}$ & $\begin{array}{c}\text { Malignant } \\
\text { stricture } \\
\mathbf{N = 2 2}\end{array}$ & $\begin{array}{c}\mathbf{P C} \\
\mathbf{N = 7}\end{array}$ & $\begin{array}{c}\text { CCA } \\
\mathbf{N = 1 5}\end{array}$ & $\begin{array}{c}\text { Benign } \\
\text { stricture } \\
\mathbf{N = 1 8}\end{array}$ \\
\hline MRI/MRCP & $9(41 \%)$ & $3(43 \%)$ & $6(40 \%)$ & $9(50 \%)$ \\
\hline Spiral CT & $21(96 \%)$ & $6(86 \%)$ & $15(100 \%)$ & $12(67 \%)$ \\
\hline EUS + FNAB & $1(4.6 \%)$ & $1(14 \%)$ & 0 & $1(6 \%)$ \\
\hline Histology/cytology & $6(27 \%)^{\mathrm{a}}$ & $1(14 \%)$ & $5(33 \%)$ & $2(12 \%)$ \\
\hline Histology (surgery) & $7(32 \%)$ & $4(57 \%)$ & $3(20 \%)$ & $6(33 \%)$ \\
\hline Radical surgery & $3(18 \%)$ & $1(14 \%)$ & $2(13 \%$ & 0 \\
\hline Chemo/radiotherapy & $6(27 \%)^{\mathrm{b}}$ & 0 & $6(40 \%)$ & 0 \\
\hline Death & $19(86 \%)$ & $6(86 \%)$ & $13(87 \%)$ & $5(28 \%)^{\mathrm{c}}$ \\
\hline
\end{tabular}

PC - pancreatic cancer, CCA - cholangiocarcinoma, MRI - magnetic resonance imaging, MRCP - magnetic resonance cholangiopancreatography, CT - computed tomography, EUS - endoscopic ultrasonography, FNAB - fine needle biopsy; ERCP - endoscopic retrograde cholangiography, aCCA in 5 cases, ${ }^{\mathrm{b}} \mathrm{CCA}$ in all cases, ${ }^{c} 2$ deaths due to postransplant complications, 2 deaths due to postoperative non-transplant complications, 1 death -heart infarction in a 74 years-old man.

Table 1: Diagnostic procedures and follow-up data of patients with malignant and benign common bile duct strictures. 


\begin{tabular}{|c|c|c|c|}
\hline Variable (reference values) & $\begin{array}{c}\text { Malignant } \\
\text { strictures } \\
\mathbf{N = 2 2}\end{array}$ & $\begin{array}{c}\text { Benign } \\
\text { strictures } \\
\mathbf{N = 1 8}\end{array}$ & $\boldsymbol{P}$ value \\
\hline Age (yrs \pm SD) & $60.9 \pm 11.5$ & $58.3 \pm 19.5$ & 0.59 \\
\hline Female/male & $8 / 14$ & $9 / 9$ & 0.38 \\
\hline BMI (kg/m² \pm SD) & $24.8 \pm 4.9$ & $26.6 \pm 5.2$ & 0.27 \\
\hline Hemoglobin (11.5-15.0 g/dL) & $12.1 \pm 1.4$ & $13.2 \pm 1.6$ & 0.03 \\
\hline White blood cells $(4.0-10.0 \mathrm{G} / \mathrm{L})$ & $8.4 \pm 3.1$ & $7.8 \pm 4.2$ & 0.61 \\
\hline Platelets $(130-400 \mathrm{G} / \mathrm{L})$ & $323 \pm 131$ & $213 \pm 105$ & 0.006 \\
\hline CRP $(<5 \mathrm{mg} / \mathrm{L})$ & $37.2 \pm 45.5$ & $24.4 \pm 54.2$ & 0.42 \\
\hline ALT $(<34$ U/L) & $150 \pm 110$ & $43.6 \pm 29.6$ & $<0.001$ \\
\hline AST (<31 U/L) & $167 \pm 143$ & $47.8 \pm 29.4$ & 0.001 \\
\hline Alkaline phosphatase $(38-$ & $451 \pm 171$ & $291 \pm 411$ & 0.10 \\
\hline $126 \mathrm{~L} / \mathrm{L})$ & $664 \pm 462$ & $192 \pm 204$ & $<0.001$ \\
\hline GGTP (<38 U/L) & $18.8 \pm 12.6$ & $3.4 \pm 3.8$ & $<0.001$ \\
\hline Bilirubin $(0.3-1.2 \mathrm{mg} / \mathrm{dL})$ & & & \\
\hline
\end{tabular}

Parameters presented as frequencies or mean values $\pm \mathrm{SD}$; BMI - body mass index; CRP- C-reactive protein; ALT- alanine transaminase; AST- aspartate transaminase; GGTP- gamma-glutamyltranspeptidase.

Table 2: Characteristics of patients with malignant and benign biliary strictures.

$\pm 29.4, \mathrm{p}<0.001)$, GGTP level $(664 \pm 462$ vs. $192 \pm 203, \mathrm{p}<0.001)$ and much more pronounced jaundice (bilirubin level $18.8 \pm 12.6$ vs. $3.4 \pm$ $3.8, \mathrm{p}<0.0001)$. Leucocytes counts, CRP level and alkaline phosphatase activity were similar in both groups.

\section{Follow-up data}

Follow-up data were collected until September 2013 by reviewing medical records of hospitalized patients or telephone contact. The mean follow-up was significantly longer for patients with benign diseases $(17.3 \pm 6.5$ months $)$ than for patients with malignancies $(10.3$ \pm 8.1 months, $\mathrm{p}=0.01$ ) due to survival. During follow-up 19 patients died because of progression of malignant disease and 5 patients died because of complications of benign biliary stricture $(p<0.01)$. All 10 patients with Klatskin tumor died and none of them was earlier operated due to advanced stage of disease. Two of 5 patients with extrahepatic cholangiocarcinoma were radically operated and are still alive and one patient with distal tumour appeared to be unresectable during laparotomy and died of disease progression. Four patients with pancreatic cancer were operated, with radical surgery only in one of them and only that one is still alive. Palliative radiotherapy and chemotherapy were applied both in six patients with cholangiocarcinoma. Till the end of the study all patients with malignant strictures except three radically operated died of progression of disease.

Two of patients with primary sclerosing cholangitis who underwent ortotopic liver transplantation died because of post-transplant complications. During the follow-up three patients of the benign group died of co-morbidities.

Serum levels of CA 19-9, CEA, IGF-I, Il-6 and Tu M2-PK in patients with malignant and benign biliary strictures: Serum levels of CA19-9, CEA, IGF-I and Il-6 and plasma level of Tu-M2-PK are shown in Table 3. Serum CA19-9 and CEA levels were significantly higher in patients with pancreatobiliary cancer than in those with benign biliary strictures $(p=0.002$ and $p=0.0001$, respectively). Serum CA19-9 level was significantly different in both malignant groups cholangiocarcinoma and pancreatic cancer groups in comparison to benign group ( $p=0.04$ and $p=0.02$, respectively). CA19-9 levels were similar in patients with CCA and those with pancreatic cancer. The CEA concentrations were higher in both malignant groups than in benign group and significant difference was notable between patients with both tumors: cholangiocarcinoma and pancreatic cancer and patients with benign diseases $(\mathrm{p}=0.002$ and $\mathrm{p}=0.02$, respectively). The CEA levels were statistically comparable between patients with CCA and pancreatic cancer $(p=0.07)$. The IGF-I serum levels were significantly different between patients with pancreatobiliary cancer and patients with benign biliary strictures ( $\mathrm{p}=0.03$ ). The IGF-I serum levels tended to be lower in patients with both malignant tumors in comparison to patients with benign diseases but for pancreatic cancer the difference was more pronounced than for cholangiocarcinoma $(p=0.05$ and $\mathrm{p}=0.11$, respectively). Patients with CCA and with pancreatic cancer had comparable serum levels of IGF-I. Serum Il-6 levels were higher in patients with malignant than benign diseases $(p=0.04)$ but differences between patients with cholangiocarcinoma, pancreatic cancer and benign disease were not significant. Patients with CCA and with pancreatic cancer had the same serum Il-6 concentrations. Tu-M2-PK concentrations did not show any differences between three groups.

Bile levels of IGF-I, Il-6 and Tu-M2-PK in patients with malignant and with benign biliary strictures: Bile IGF-I levels were statistically comparable between patients with malignant and with benign strictures (Table 4). Nevertheless bile IGF-I levels were significantly higher in pancreatic cancer group than in benign group ( $966.0 \mathrm{vs.} 90.6 \mathrm{ng} / \mathrm{ml}, \mathrm{p}=0.01)$ and in cholangiocarcinoma group $(966.0$ vs. $137.1 \mathrm{ng} / \mathrm{ml}, \mathrm{p}=0.03)$. The difference of biliary IGF-I levels between CCA and benign groups were not statistically significant $(\mathrm{p}=0.29)$.

Bile Il-6 levels were comparable between pancreatobiliary and benign disease groups as well as between both malignant groups. Similar results were calculated for bile Tu M2-PK; no differences were detected between malignancy group and benign stricture group and between CCA and pancreatic cancer group.

\begin{tabular}{|c|c|c|c|c|c|}
\hline $\begin{array}{c}\text { Serum } \\
\text { biomarker }\end{array}$ & $\begin{array}{c}\text { Malignant } \\
\text { stricture }\end{array}$ & CCA & PC & $\begin{array}{c}\text { Benign } \\
\text { stricture }\end{array}$ & $\begin{array}{c}\text { P statistics } \\
\text { Malignant } \\
\text { vs. Benign } \\
\text { stricture }\end{array}$ \\
\hline $\begin{array}{c}\text { CA 19-9 (U/ } \\
\mathrm{mL})\end{array}$ & $\begin{array}{c}5689 \pm \\
13001\end{array}$ & $\begin{array}{c}7249 \pm \\
15405^{*}\end{array}$ & $\begin{array}{c}1275 \pm \\
2114^{*}\end{array}$ & $38.9 \pm 75$ & 0.002 \\
\hline $\begin{array}{c}\mathrm{CEA} \\
(\mathrm{ng} / \mathrm{mL})\end{array}$ & $27.5 \pm 65$ & $10.5 \pm 20^{*}$ & $63.9 \pm 108^{*}$ & $1.9 \pm 1.0$ & 0.0001 \\
\hline $\begin{array}{c}\text { IGF-I } \\
(\mathrm{ng} / \mathrm{mL})\end{array}$ & $74.4 \pm 44$ & $82.3 \pm 45$ & $57.4 \pm 44^{*}$ & $117 \pm 73$ & 0.03 \\
\hline $\begin{array}{c}\mathrm{II-6} \\
(\mathrm{pg} / \mathrm{mL})\end{array}$ & $37.1 \pm 48$ & $32.2 \pm 43$ & $47.8 \pm 59$ & $17 \pm 23$ & 0.04 \\
\hline $\begin{array}{c}\mathrm{Tu} \mathrm{M} 2-\mathrm{PK} \\
(\mathrm{U} / \mathrm{mL})\end{array}$ & $102 \pm 75$ & $100 \pm 100$ & $121 \pm 102$ & $114 \pm 101$ & 0.67 \\
\hline
\end{tabular}

Data are presented as mean values $\pm S D$; ${ }^{*} p<0.05$; different from benign biliary stricture; CCA - cholangiocarcinoma; PC - pancreatic cancer; CA 19-9-carbohydrate antigens 19-9; CEA -carcinoembryonic antigen, IGF-I - insulinlike growth factor I; II-6 - interleukin 6; Tu M2-PK - tumor M2 pyruvate kinase

Table 3: Biomarkers measured in the serum of patients with malignant and benign biliary strictures.

\begin{tabular}{|c|c|c|c|c|c|}
\hline $\begin{array}{c}\text { Biliary } \\
\text { biomarker } \\
\text { (unit) }\end{array}$ & $\begin{array}{c}\text { Malignant } \\
\text { stricture }\end{array}$ & CCA & PC & $\begin{array}{c}\text { Benign } \\
\text { stricture }\end{array}$ & $\begin{array}{c}\text { P statistics } \\
\text { Malignant } \\
\text { vs. Benign } \\
\text { stricture }\end{array}$ \\
\hline $\begin{array}{c}\text { IGF-I } \\
\text { (ng/mL) }\end{array}$ & $401 \pm 873$ & $137 \pm 152^{\#}$ & $966 \pm 1439^{*}$ & $90.6 \pm 91.4$ & 0.14 \\
\hline $\begin{array}{c}\text { II-6 } \\
\text { (pg/mL) }\end{array}$ & $81 \pm 185$ & $87.1 \pm 210$ & $67.8 \pm 131$ & $34.6 \pm 80.1$ & 0.32 \\
\hline $\begin{array}{c}\text { Tu M2-PK } \\
(\mathrm{U} / \mathrm{mL})\end{array}$ & $118 \pm 97.9$ & $116 \pm 100$ & $121 \pm 102$ & $99.1 \pm 101$ & 0.55 \\
\hline
\end{tabular}

Data are presented as mean values $\pm S D$; $" p<0.05$ between $P C$ and benign stricture; ${ }^{p} p<0.05$ between CCA and PC

CCA - cholangiocarcinoma; PC - pancreatic cancer; IGF-I - insulin-like growth factor I; II-6 - interleukin 6; Tu M2-PK - tumor M2 pyruvate kinase

Table 4: Biomarkers measured in the bile of patients with malignant and benign biliary strictures. 
Citation: Budzynska A, Nowakowska-Dulawa E, Marek T, Hartleb M (2016) Serum and Bile Insulin-Like Growth Factor I, Interleukin-6 and Tumor M2-Pyruvate Kinase in Differentiation Malignant from Benign Biliary Strictures - Preliminary Report. Med chem (Los Angeles) 6: 429-434. doi:10.4172/2161-0444.1000381

Correlations between biomarkers: The relationships between tumor markers levels which showed significant difference between patients with pancreatobiliary cancer and with benign biliary strictures are shown in Table 5. The only independent from others tumor marker was IGF-I both in serum and in bile. Serum CA19-9 was significantly correlated with serum CEA. Serum CEA except CA19-9 was also correlated with serum Il-6. However, the correlation coefficients for all these parameters were very low $(<0.5)$. In addition serum IGF-I correlated with hemoglobin, ALT, AST, AP, GGTP and bilirubin levels and serum Il-6 correlated with hemoglobin level, leukocytes count, CRP and bilirubin level. But all the correlation coefficients were low $(<0.5)$.

Diagnostic accuracy of biomarkers in discriminating between malignant and benign biliary strictures: Figure 1 shows the ROC curve obtained by plotting the True Positive Probability (sensitivity) against the False Negative Probability (1-specificity) for the CA19-9, CEA, serum and bile IGF-I and serum Il-6 to predict the presence of malignancy. The AUC-ROCs for CA19-9, CEA, serum IGF-I, bile IGF-I and serum Il- 6 were $0.855,0.794,0.336,0.583$ and 0.606 , respectively (Table 5). The estimated cut-off values for CA19-9, CEA, serum IGF-I, bile IGF-I and serum Il-6 were $16.4 \mathrm{U} / \mathrm{ml}, 2.62 \mathrm{ng} / \mathrm{ml}, 7.18 \mathrm{ng} / \mathrm{ml}$, $189.9 \mathrm{ng} / \mathrm{ml}$ and $2.01 \mathrm{pg} / \mathrm{ml}$, respectively. The sensitivity, specificity and accuracy for diagnosis of malignant biliary duct strictures for the established cut-off levels are shown in Table 6. Biliary IGF-I level was significantly higher in patients with pancreatic cancer than in patients with CCA and benign diseases. Then the diagnostic accuracy of biliary IGF-I to predict the presence of pancreatic cancer was assessed. The AUC-ROC for biliary IGF-I was 0.693 with cut-off point at $3000 \mathrm{ng} /$ $\mathrm{ml}$, sensitivity of $28.6 \%$, specificity of $100 \%$ and accuracy of $87.5 \%$. The accuracy of four biomarkers to predict the malignant biliary strictures was compared by significance of differences of AUC, which showed that performance of CA 19-9 was comparable to that of CEA $(0.854$ vs. $0.794, p=0.47)$, but significantly better than that of serum IGF-I ( 0.854 vs. $0.336, \mathrm{p}<0.001)$, biliary IGF-I $(0.854$ vs. $0.583, \mathrm{p}=0.02)$ and serum Il-6 ( 0.854 vs. $0.606, \mathrm{p}=0.03)$. The performance of CEA was significantly better than that of serum IGF-I ( 0.794 vs. $0.336, p=0.0001)$, and statistically not different than that of biliary IGF-I ( 0.794 vs. 0.583 , $\mathrm{p}=0.1$ ) and serum Il-6 (0.792 vs. $0.606, \mathrm{p}=0.06)$.

\section{Discussion}

The main finding of our preliminary study is that bile concentration of IGF-I in patients with extrahepatic biliary duct

\begin{tabular}{|c|c|c|c|c|}
\hline Biomarkers & CEA & & & \\
\hline CEA & $\mathrm{x}$ & CA 19-9 & & \\
\hline CA 19-9 & $0.4980^{*}$ & $\mathrm{x}$ & sIGF-I & \\
\hline sIGF-I & -0.2144 & -0.2458 & $\mathrm{x}$ & bIGF-I \\
\hline bIGF-I & 0.0030 & 0.0716 & 0.0306 & $\mathrm{x}$ \\
\hline II-6 & $0.3465^{*}$ & 0.0907 & -0.0484 & 0.0686 \\
\hline
\end{tabular}

" $\mathrm{p}<0.05$; s - serum, b - bile

Table 5: Relationships (correlation coefficients) of biomarkers in all investigated patients.

\begin{tabular}{|c|c|c|c|c|c|}
\hline Biomarker & AUC-ROC & $\begin{array}{c}\text { Cut-off } \\
\text { values }\end{array}$ & $\begin{array}{c}\text { Sensitivity } \\
\%\end{array}$ & $\begin{array}{c}\text { Specificity } \\
\%\end{array}$ & $\begin{array}{c}\text { Accuracy } \\
\%\end{array}$ \\
\hline CA 19-9 & 0.855 & $16.4 \mathrm{U} / \mathrm{mL}$ & 95.5 & 55.6 & 77.5 \\
\hline CEA & 0.794 & $2.62 \mathrm{ng} / \mathrm{mL}$ & 72.7 & 77.8 & 75.0 \\
\hline Serum IGF-I & 0.336 & $7.18 \mathrm{ng} / \mathrm{mL}$ & 100 & 56.4 & 57.5 \\
\hline Bile IGF-I & 0.583 & $189.9 \mathrm{ng} / \mathrm{mL}$ & 45.5 & 94.4 & 67.5 \\
\hline Serum II-6 & 0.606 & $2.01 \mathrm{pg} / \mathrm{mL}$ & 81.8 & 38.9 & 62.5 \\
\hline
\end{tabular}

AUC-ROC - area under ROC curve

Table 6: Diagnostic accuracy of biomarkers in differentiating malignant from benign biliary strictures.

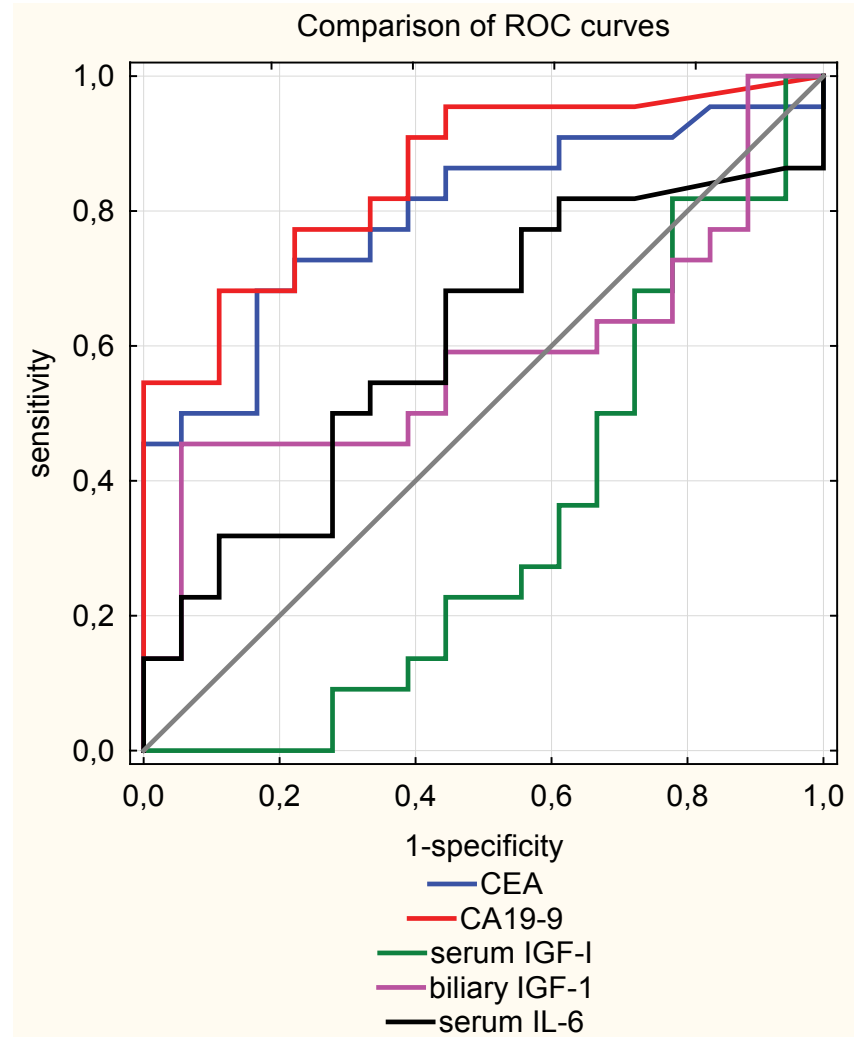

Figure 1: The ROC curves for CA 19-9, CEA, serum and bile IGF-I and serum II-6 predicting the presence of malignancy of bile ducts.

stricture may differentiate pancreatic cancer from either CCA or benign biliary disease. IGF-I is a well-recognized stimulator of cancer cell proliferation and potent inhibitor of apoptosis [22,23]. Expression of IGF-I receptor was detected in samples of resected pancreatic cancer and was associated with higher histological grade, tumor aggressiveness and poor prognosis [24,25]. It was also shown that growth hormone $(\mathrm{GH})$ promotes the proliferation and differentiation of bile duct cancer cell via IGF-I axis [26]. Alvaro et al. [6] found 1520 -fold higher IGF-I biliary concentration in patients with extrahepatic CCA than in patients with pancreatic cancer or benign diseases of biliary tree. Although results in these two studies are inconsistent and finding the most likely explanation is difficult, biliary IGF-I seems to be a promising diagnostic biomarker for biliary malignancy. Thus, further studies including larger cohorts of patients are needed.

Surprisingly, serum levels of IGF-I in our patients with malignant biliary occlusions were significantly lower than in patients with benign biliary stricture. Results of other studies on serum IGF-I in pancreatobiliary cancers are contradictory showing increased or normal levels [27-29]. Alvaro et al. showed [10] increased expression of IGF-I in human intrahepatic CCA, but the serum IGF-I levels were not significantly different between patients with pancreatic cancer, CCA and inflammatory biliary disease, although when two malignant groups have been combined the serum IGF-I was significantly higher than in inflammatory group (6). Serum levels of IGF-I may be influenced by different factors including age, menopause, diet, physical activity and many pathological conditions [30,31]. It should also be noted that in most patients with benign biliary stricture the overt cholangitis was present, therefore, an influence of bacterial infection on IGF-I cannot be excluded. Moreover, patients with pancreatic cancer had lower body weight than patients with benign disease (data not shown), while it is 
Citation: Budzynska A, Nowakowska-Dulawa E, Marek T, Hartleb M (2016) Serum and Bile Insulin-Like Growth Factor I, Interleukin-6 and Tumor M2-Pyruvate Kinase in Differentiation Malignant from Benign Biliary Strictures - Preliminary Report. Med chem (Los Angeles) 6: $429-434$. doi:10.4172/2161-0444.1000381

known that body mass index shows inverse correlation with serum IGF-I level $[31,32]$. Low levels of IGF-I were also reported in critically ill $[33,34]$ and gastric cancer patients [35-38]. Taking into account inconclusive results of different studies, the diagnostic utility of serum IGF-I in pancreatobiliary malignancies seems to be limited.

Il-6 is a multifunctional inflammatory cytokine, which plays a major role in the response of biliary and hepatic epithelia to inflammation. The relationship between chronic inflammation and cancer has been well established [13]. Serum Il-6 was shown to be accurate diagnostic and prognostic marker in CCA, able to distinguish CCA from benign biliary disease [16]. Elevated serum concentration of Il-6 in patients with CCA declined rapidly after neoplasm resection [17] and after photodynamic therapy [39]. In our study, serum interleukin 6 levels were significantly higher in patients with pancreatobiliary malignancies than in patients with benign biliary strictures, but their diagnostic accuracy as shown by AUROC was below that of CA 19-9 and CEA. In addition, according to expectations Il- 6 showed low specificity for cancer in both the serum and bile. The difference in opinions on diagnostic yield of Il-6 may be due to diverse study populations since Taiwanese cases of CCA are mostly induced by parasitic infestations [16]. It would be important to prove the usefulness of Il- 6 in screening for CCA in primary sclerosing cholangitis, which is a well-recognized precancerous state and the early diagnosis of CCA in this disease is highly challenging.

CA 19-9 and CEA, commonly used biomarkers of pancreatobiliary cancers, showed in our study acceptable sensitivity and specificity in detecting malignant bile duct strictures. Both markers differentiated the CCA and pancreatic cancer from benign diseases. Although biliary cancer is of intestinal type, the CEA seems to better reflect poor prognosis in patients with pancreatic cancer than CCA.

Tumor M2 pyruvate-kinase has been identified as a promising marker for CCA, although results of published studies are controversial. Li et al. [21] found that plasma level of Tu M2-PK was significantly increased in patients with CCA as compared to healthy controls and the diagnostic performance of Tu M2-PK was higher than that of CA 19-9. Dhar et al. [20] reported that Tu M2-PK levels measured in both the plasma and bile were significantly higher in patients with biliary malignancies then in healthy controls, with better diagnostic accuracy of bile levels (sensitivity $90.3 \%$, specificity $84.3 \%$ ). In both studies Tu M2-PK levels correlated either with the tumor stage or clinical outcome. In the meta-analysis plasma Tu M2-PK correlated with the stage of pancreatic cancer and the pooled sensitivity and specificity for diagnosis of this cancer was $60 \%$ and $95 \%$, respectively. On the other side, Joergensen et al. [37] did not confirm diagnostic utility of Tu M2-PK in patients with pancreatic cancer. Similarly, our study failed to detect any significant difference in Tu M2-PK measured in bile or plasma between patients with pancreatobiliary malignancies and benign biliary strictures. There are some circumstances, which impact the plasma Tu M2-PK concentration. Tu M2-PK expression was found in neutrophils, but not lymphocytes and its levels may be raised by inflammatory conditions, responsible for development of systemic inflammatory response. In our study the patients with benign biliary diseases presented symptoms of cholangitis that might be the cause of increased release of Tu M2-PK.

The major disadvantage of our study in the small sample size, which enables comparisons of biomarker levels with different stages of malignant diseases. The study was performed in single center and the diagnosis was based on many approaches with definite confirmation in follow-up history. The lack of histologic examination is common in cholangiocarcinoma patients and obtain in the best case in $60 \%$ of cases as most of them are not suitable for surgery.

In conclusion, we found that bile IGF-I was relatively specific for pancreatic cancer, but more studies with patients at different stages of this disease are needed for determination of the diagnostic utility of this promising biomarker. Serum IGF-I and Il-6 differentiated malignant from benign biliary strictures, however, the discriminating power of these variables was inferior to that of CA19-9 and CEA. Therefore, use of serum IGF-I and Il-6 may play only an auxiliary role in diagnosis of pancreatobiliary cancer.

\section{Acknowledgements}

Supported by institutional scientific Grant No. KNW 1-104/10 from Medical University of Silesia in Katowice.

\section{References}

1. Khan SA, Davidson BR, Goldin RD, Heaton N, Karani J, et al. (2012) Guidelines for the diagnosis and treatment of cholangiocarcinoma: an update. Gut 61: 1657-1669.

2. Weber A, von Weyhern C, Fend F, Schneider J, Neu B, et al. (2008) Endoscopic transpapillary brush cytology and forceps biopsy in patients with hilar cholangiocarcinoma. World J Gastroenterol 14: 1097-1101.

3. Patel AH, Harnois DM, Klee GG, LaRusso NF, Gores GJ (2000) The utility of CA 19-9 in the diagnoses of cholangiocarcinoma in patients without primary sclerosing cholangitis. Am J Gastroenterol 95: 204-207.

4. Levy C, Lymp J, Angulo P, Gores GJ, Larusso N, et al. (2005) The value of serum CA 19-9 in predicting cholangiocarcinomas in patients with primary sclerosing cholangitis. Dig Dis Sci 50: 1734-1740.

5. Tempero MA, Uchida E, Takasaki H, Burnett DA, Steplewski Z, et al. (1987) Relationship of carbohydrate antigen 19-9 and Lewis antigens in pancreatic cancer. Cancer Res 47: 5501-5503.

6. Alvaro D, Macarri G, Mancino MG, Marzioni M, Bragazzi M, et al. (2007) Serum and biliary insulin-like growth factor I and vascular endothelial growth factor in determining the cause of obstructive cholestasis. Ann Intern Med 147: 451-459.

7. Zabron AA, Horneffer-van der Sluis VM, Wadsworth CA, Laird F, Gierula M, et al. (2011) Elevated levels of neutrophil gelatinase-associated lipocalin in bile from patients with malignant pancreatobiliary disease. Am J Gastroenterol 106: 1711-1717.

8. Budzynska A, Nowakowska-Dulawa E, Marek T, Boldys H, Nowak A, et al. (2013) Differentiation of pancreatobiliary cancer from bening biliary strictures using neutrophil gelatinase-associated lipocalin. J Physiol Pharmacol 64: 109-114.

9. Navaneethan U, Gutierrez NG, Jegadeesan R, Venkatesh PG, Poptic E, et al (2013) Vascular endothelial growth factor levels in bile distinguishes pancreatic cancer from other etiologies of biliary stricture: a pilot study. Dig Dis Sci 58: 2986-2992.

10. Alvaro D, Barbaro B, Franchitto A, Onori P, Glaser SS, et al. (2006) Estrogens and insulin-like growth factor 1 modulate neoplastic cell growth in human cholangiocarcinoma. Am J Pathol 169: 877-888.

11. Lin Y, Tamakoshi A, Kikuchi S, Yagyu K, Obata Y, et al. (2004) Serum insulinlike growth factor-I, insulin-like growth factor binding protein-3, and the risk of pancreatic cancer death. Int J Cancer 110: 584-588.

12. Meng F, Yamagiwa Y, Ueno Y, Patel T (2006) Over-expression of interleukin-6 enhances cell survival and transformed cell growth in human malignant cholangiocytes. J Hepatol 44: 1055-1065.

13. Grivennikov SI, Greten FR, Karin M (2010) Immunity, inflammation, and cancer Cell 140: 883-899.

14. Tangkijvanich $P$, Thong-ngam $D$, Theamboonlers $A$, Hanvivatvong $O$ Kullavanijaya P, et al. (2004) Diagnostic role of serum interleukin 6 and CA 19-9 in patients with cholangiocarcinoma. Hepatogastroenterology 51: 15-19.

15. Goydos JS, Brumfield AM, Frezza E, Booth A, Lotze MT, et al. (1998) Marked elevation of serum interleukin- 6 in patients with cholangiocarcinoma: validation of utility as a clinical marker. Ann Surg 227: 398-404.

16. Cheon YK, Cho YD, Moon JH, Jang JY, Kim YS, et al. (2007) Diagnostic utility of interleukin-6 (IL-6) for primary bile duct cancer and changes in serum IL-6 levels following photodynamic therapy. Am J Gastroenterol 102: 2164-2170.

17. Eigenbrodt E, Reinacher M, Scheefers-Borchel U, Scheefers H, Friis R (1992) Double role for pyruvate kinase type M2 in the expansion of phosphometabolite pools found in tumor cells. Crit Rev Oncog 3: 91-115. 
Citation: Budzynska A, Nowakowska-Dulawa E, Marek T, Hartleb M (2016) Serum and Bile Insulin-Like Growth Factor I, Interleukin-6 and Tumor M2-Pyruvate Kinase in Differentiation Malignant from Benign Biliary Strictures - Preliminary Report. Med chem (Los Angeles) 6: $429-434$. doi:10.4172/2161-0444.1000381

18. Dhar DK, Olde Damink SW, Brindley JH, Godfrey A, Chapman MH, et al. (2013) Pyruvate kinase M2 is a novel diagnostic marker and predicts tumor progression in human biliary tract cancer. Cancer 119: 575-585.

19. Li YG, Zhang N (2009) Clinical significance of serum tumour M2-PK and CA199 detection in the diagnosis of cholangiocarcinoma. Dig Liver Dis 41: 605-608.

20. Ahmad S, Singh N, Glazer RI (1999) Role of AKT1 in 17beta-estradiol- and insulin-like growth factor I (IGF-I)-dependent proliferation and prevention of apoptosis in MCF-7 breast carcinoma cells. Biochem Pharmacol 58: 425-430.

21. Stephen RL, Shaw LE, Larsen C, Corcoran D, Darbre PD (2001) Insulin-like growth factor receptor levels are regulated by cell density and by long term estrogen deprivation in MCF7 human breast cancer cells. J Biol Chem 276 : 40080-40086.

22. Hirakawa T, Yashiro M, Murata A, Hirata K, Kimura K, et al. (2013) IGF-1 receptor and IGF binding protein-3 might predict prognosis of patients with resectable pancreatic cancer. BMC Cancer 13: 392.

23. Valsecchi ME, McDonald M, Brody JR, Hyslop T, Freydin B, et al. (2012) Epidermal growth factor receptor and insulin-like growth factor 1 receptor expression predict poor survival in pancreatic ductal adenocarcinoma. Cancer 118: 3484-3493.

24. Cai HH, Sun YM, Bai JF, Shi Y, Zhao HL, et al. (2008) Relationship between the GH-IGFs axis and the proliferation of bile duct cancer cell line QBC939 in vitro. Hepatobiliary Pancreat Dis Int 7: 76-81.

25. Karna E, Surazynski A, OrÅ,owski K, Å aszkiewicz J, Puchalski Z, et al. (2002) Serum and tissue level of insulin-like growth factor-I (IGF-I) and IGF-I binding proteins as an index of pancreatitis and pancreatic cancer. Int J Exp Pathol 83: 239-245.

26. Stolzenberg-Solomon RZ, Limburg P, Pollak M, Taylor PR, Virtamo J, et al. (2004) Insulin-like growth factor (IGF)-1, IGF-binding protein-3, and pancreatic cancer in male smokers. Cancer Epidemiol Biomarkers Prev 13: 438-444.

27. Rohrmann S, Grote VA, Becker S, Rinaldi S, Tjønneland A, et al. (2012) Concentrations of IGF-I and IGFBP-3 and pancreatic cancer risk in the European Prospective Investigation into Cancer and Nutrition. $\mathrm{Br} \mathrm{J}$ Cancer 106: 1004-1010.

28. Capri M, Salvioli S, Sevini F, Valensin S, Celani L, et al. (2006) The genetics of human longevity. Ann N Y Acad Sci 1067: 252-263.
29. Juul A (2003) Serum levels of insulin-like growth factor I and its binding proteins in health and disease. Growth Horm IGF Res 13: 113-170.

30. Copeland KC, Colletti RB, Devlin JT, McAuliffe TL (1990) The relationship between insulin-like growth factor-I, adiposity, and aging. Metabolism 39: 584-587.

31. Timmins AC, Cotterill AM, Hughes SC, Holly JM, Ross RJ, et al. (1996) Critical illness is associated with low circulating concentrations of insulin-like growth factors-I and -II, alterations in insulin-like growth factor binding proteins, and induction of an insulin-like growth factor binding protein 3 protease. Crit Care Med. 24: 1460-1466.

32. Baxter RC, Hawker FH, To C, Stewart PM, Holman SR (1998) Thirty-day monitoring of insulin-like growth factors and their binding proteins in intensive care unit patients. Growth Horm IGF Res 8: 455-463.

33. Lee DY, Yang DH, Kang CW, Kim SJ, Joo CU, et al. (1997) Serum insulin-like growth factors (IGFs) and IGF binding protein (IGFBP)-3 in patients with gastric cancer: IGFBP-3 protease activity induced by surgery. J Korean Med Sci 12: 32-39.

34. Ortner MA (2009) Photodynamic therapy for cholangiocarcinoma: overview and new developments. Curr Opin Gastroenterol 25: 472-476.

35. Sripa B, Thinkhamrop B, Mairiang E, Laha T, Kaewkes S, et al. (2012) Elevated plasma IL-6 associates with increased risk of advanced fibrosis and cholangiocarcinoma in individuals infected by Opisthorchis viverrini. PLoS Negl Trop Dis 6: e1654.

36. Kumar Y, Gurusamy K, Pamecha V, Davidson BR (2007) Tumor M2-pyruvate kinase as tumor marker in exocrine pancreatic cancer a meta-analysis. Pancreas 35: 114-119.

37. Joergensen MT, Heegaard NH, Schaffalitzky de Muckadell OB (2010) Comparison of plasma Tu-M2-PK and CA19-9 in pancreatic cancer. Pancreas 39: 243-247.

38. Mazurek S, Grimm H, Oehmke M, Weisse G, Teigelkamp S, et al. (2000) Tumor M2-PK and glutaminolytic enzymes in the metabolic shift of tumor cells. Anticancer Res 20: 5151-5154.

39. Goonetilleke KS, Mason JM, Siriwardana P, King NK, France MW, et al (2007) Diagnostic and prognostic value of plasma tumor M2 pyruvate kinase in periampullary cancer: evidence for a novel biological marker of adverse prognosis. Pancreas 34: 318-324. 